\title{
Basal Cell Ameloblastoma
}

National Cancer Institute

\section{Source}

National Cancer Institute. Basal Cell Ameloblastoma. NCI Thesaurus. Code C39757.

A solid/multicystic ameloblastoma with follicular pattern in which the odontogenic epithelial islands are composed of uniform basaloid cells. 